\title{
PEDESTRIAN CROSSING SPEED: THE CASE OF MALAYSIA
}

\author{
Boon Hoe Goh', Kulanthayan Subramaniam², Yeong Tuck Wai ${ }^{3}$, Abdullahi Ali \\ Mohamed $^{4}$ \\ ${ }^{1,3,4}$ University of Nottingham, Malaysia Campus \\ ${ }^{2}$ University Putra Malaysia
}

Received 12 June 2012; accepted 7 September 2012

\begin{abstract}
Pedestrians are vulnerable road users, and they are always at risk when making their daily trips. Hence, roadway design and traffic control devices need to consider pedestrians' safety. Pedestrian walking speed is fundamental to any roadway and traffic control design. Unfortunately, no specific guidelines exist for pedestrian crossing speed in Malaysia. The ultimate goals of this research are to establish the local pedestrian crossing speed and to identify the contributing factors. A total of 1579 samples on pedestrian crossing speed were collected at signalised and non-signalised crosswalks. The Bivariate analysis (chi-square test) was carried out to study statistically the association of the contributing factors. The Bivariate analysis shows that crosswalk type, age and gender significantly contribute to pedestrian speed in Malaysia. However, lighting (daytime and night-time) and race are not contributing to the pedestrians' speed. Besides, pedestrians at non-signalised crosswalk have significantly faster crossing speed than at signalised crosswalk. Chi-square test also showed that children pedestrians are the fastest group, and elderly pedestrians are the slowest group in terms of pedestrian crossing speed. Moreover, male pedestrians have significantly faster crossing speed than female pedestrians do.
\end{abstract}

Keywords: walking speed, crossing speed, signalised crosswalk, non-signalised crosswalk, chi-square test.

\section{Introduction}

Road accidents were the third highest cause of death among Malaysians after heart diseases and cancer. Malaysian road accident statistics reported that 25 of every 100,000 Malaysians died in year 2003 alone (PDRM, 2004). Accident involving motorcyclists is the highest among all road users. This is followed by car drivers including passengers, and pedestrians.

The growing numbers of vehicle have contributed to traffic conflict between pedestrians and vehicles, which in serious cases lead to road accidents. To address this problem, the government had launched the Motorcycle Safety Program in 1996. This program has been successful in controlling the problem involving motorcyclists. Thus, the next group of road users that needs attention is the pedestrian, which is categorised as a vulnerable group.

As the number of the pedestrian accident is increasing, this problem needs to be addressed urgently. One of the main reasons that attributed to the high numbers

\footnotetext{
${ }^{1}$ Corresponding author : Boon-Hoe.Goh@nottingham.edu.my
} 
of pedestrian accidents is due to careless crossing. This may be due to insufficient time to cross safely, gross carelessness or other unexpected factors. To tackle this problem, one of the alternatives is to consider pedestrian crossing speed in roadway design and operation.

Unfortunately, no specific guidelines exist for pedestrian crossing speed in Malaysia. Public Work Department of Malaysia have recommended $1.22 \mathrm{~m} / \mathrm{s}(4 \mathrm{ft} / \mathrm{s})$ as walking speed, which is adopted from other country counterparts (JKR, 1987). Foreign guidelines may not necessarily be adoptable for local practices. Asian pedestrians actually walk much slower compared with Western counterparts (Tanaboriboon et al., 1986; Tanaboriboon and Guyano, 1991). Therefore, to enhance pedestrian safety, there is a significant need to carry out a research to determine the pedestrian crossing speed in Malaysia and the factors contributing to the crossing speed.

The main objective for this study is to determine the Malaysian pedestrian crossing speed for both signalised and non-signalised crosswalks, and to study the contributing factors that affect the crossing speed.

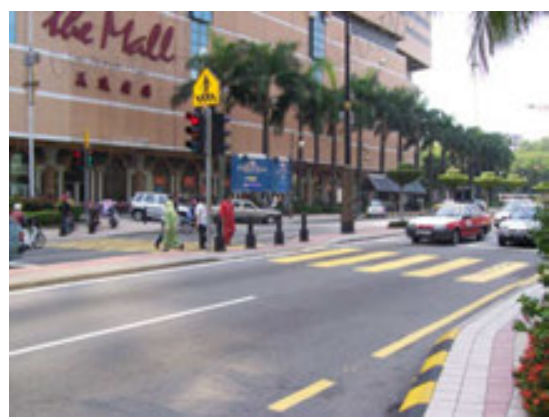

\section{Methodology}

The study was carried out in Kuala Lumpur, the capital of Malaysia. Kuala Lumpur is selected due to its high population and corresponding pedestrian activities and high capacity of pedestrian crossing. A total of four study locations were selected within the study area to represent the two types of crosswalk: signalised and non-signalised crosswalk. However, the selected sites are not similar in terms of traffic volume and numbers of lane. For this study, the signalised crosswalk (Fig. 1 and Fig. 2) is defined as a crosswalk with provision for pedestrian crossing by assigning the right of way using traffic device, such as signal timing. Meanwhile, non-signalised crosswalk (Fig. 3 and Fig. 4) represents crosswalk without proper provision for pedestrian crossing. Specifically in this study, the non-signalised crosswalk used is a type of crosswalk within the vicinity of major traffic generating landmark.

A total of 1579 samples were collected both at signalised and non-signalised control type crosswalk during daytime and night time. Out of these, 907 samples were collected at signalised crosswalk, while the rest of the 672 samples were observed at non-signalised crosswalk. The samples were further broken down into

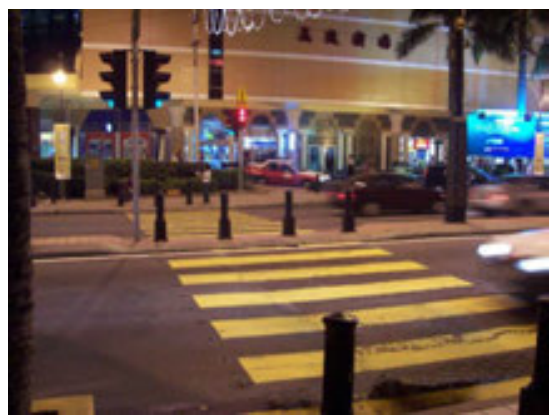

Fig. 1.

Signalised Crosswalk that is Located in between the Mall Shopping Complex and Pan Pacific Hotel during Daytime (L) and Night Time (R) 

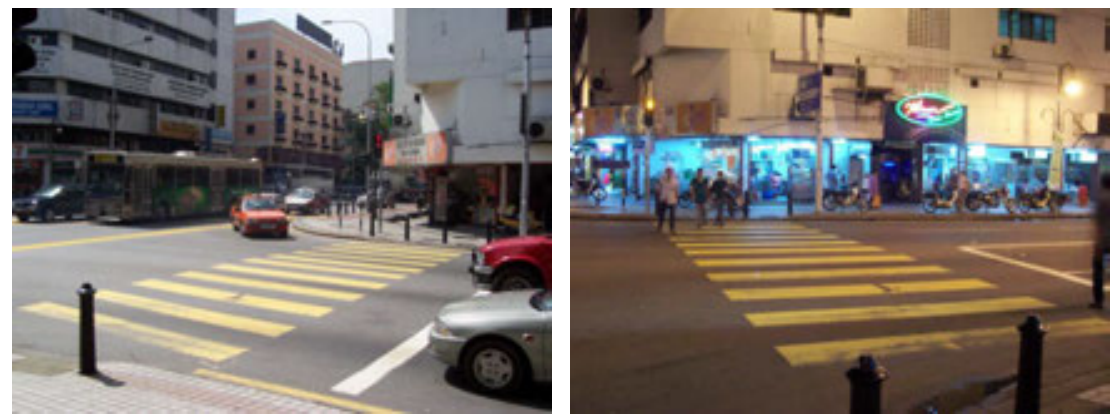

Fig. 2.

Signalised Crosswalk that is Located along Jalan Putra (Putra Road) during Daytime ( $L$ ) and Night Time (R)
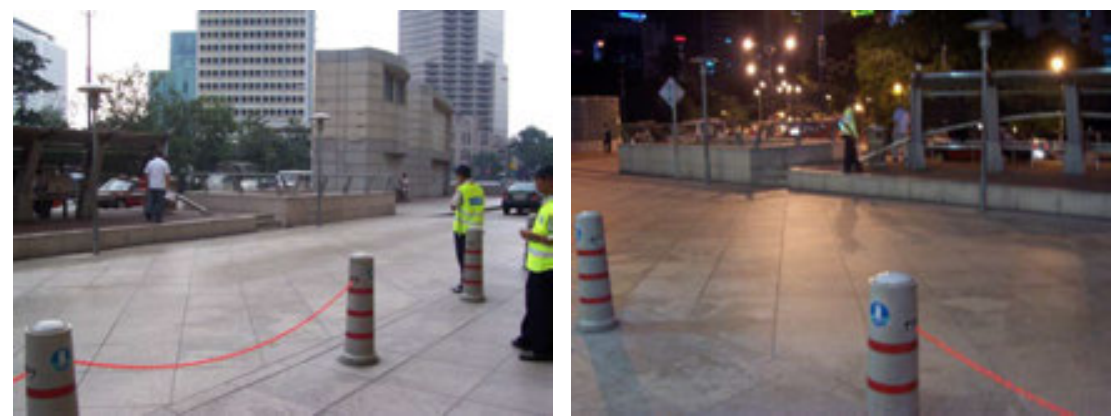

Fig. 3.

Non-Signalised Crosswalk that is Located at Ramlee Entrance, Suria KLCC Shopping Centre during Daytime (L) and Night Time ( $R$ )
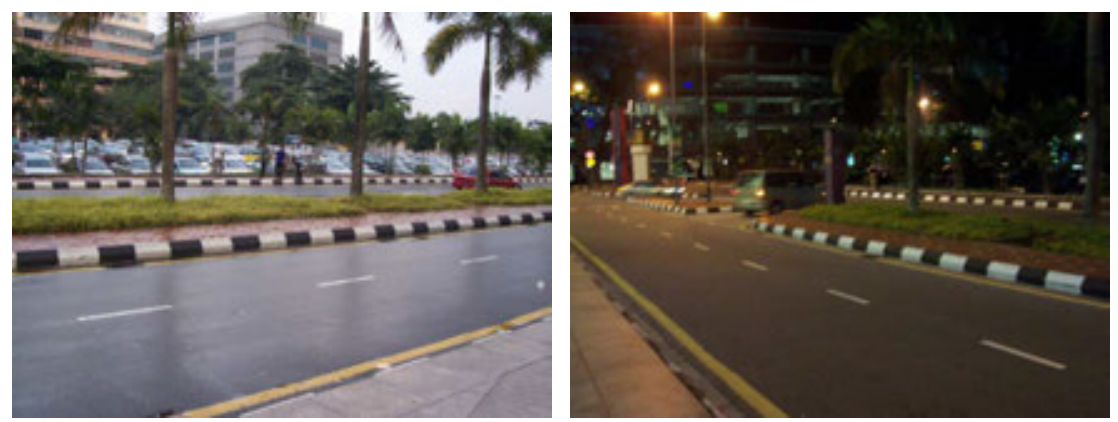

Fig. 4.

Non-Signalised Crosswalk that is Located in between Suria Shopping Centre and Maxis Tower during Daytime (L) and Night Time ( $R$ )

jitte 325 
various age categories such as, children $(<20$ years old); adult (21-54 years old) and elderly (>55 years old). For each of the category, samples were taken with consideration given on equalities of gender.

For age group, children are classified as pedestrian with age less than 20 years old. This range of age is recognised by United Nations Children's Fund (UNICEF) as teenager or children. While pedestrian with age more than 55 years old is classified as elderly or senior citizen, and this is the retirement age for Malaysian.

The data were collected through the use of data acquisition form, which consisted of two parts, namely as general information and pedestrian characteristics. In the general information part, some information such as environmental factors, traffic conditions, study location layout and some contributing factors were gathered. Whereas, in the second part, pedestrians crossing speed correspond to the pedestrian characteristics, such as gender and age were reported. A pre-test was performed on the data acquisition form to identify flaws, to verify the accuracy and to allow for amendment before the actual data collection.

On the actual data collection, two major activities were involved. The first activity involved the manual time recording for pedestrian to cross the respective crosswalk, with the assistance of stopwatch. Once the pedestrian crossed the roadway, they will be approached for a short interview. The second activity is mainly to clarify the gender and age of pedestrian and also to confirm their attire, either dark colour or bright colour. If the pedestrian refuses to be interviewed, that particular set of data will be considered as invalid and will be removed. Fig. 5 shows the algorithm of the data collection.

To obtain significant results, it is necessary to standardise the format of the information at the early stage of data collection. The primary objective is to eliminate the confusion when collecting data, which may lead to

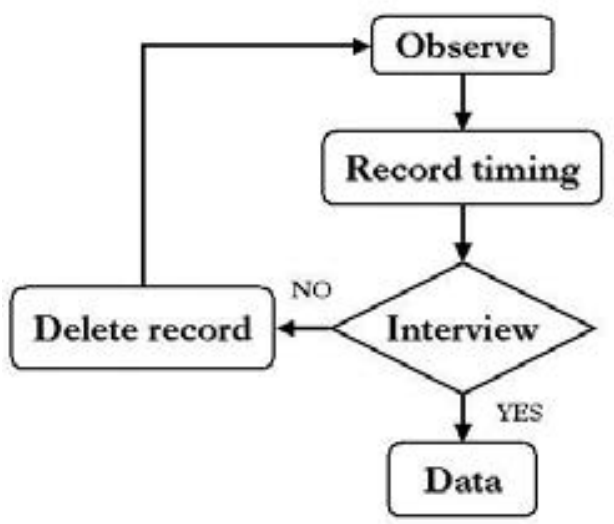

Fig. 5.

Data Collection Algorithm 
inappropriate results. A guide was used in assisting on this study and is stated below (Knoblauch et al., 1996):

The following individuals will not be observed:

1.Pedestrian walking in groups;

2. Pedestrian carrying load (e.g. children, heavy bags, suitcases);

3. Pedestrian walking with bicycle or pets;

4. Pedestrian pushing strollers;

5. Pedestrian holding hands (couple) or assisting other pedestrian;

6. Disabled pedestrian.

The following pedestrian behaviour will not be observed:

- Running;

- Crossing diagonally;

- Stopping and resting.

A group is defined as two or more pedestrians walking at the approximately same time, regardless of whether or not they were apparently friends or associates. For weather condition, dry condition is classified as clear, with dry footpath or roadway. While for wet condition, it is immediately after rain with wet footpath (sidewalk) or roadway. For this study, data will not be collected during heavy rain; due to a decrease in pedestrian activity.

According to completed researches, such as Tanaboriboon et al. (1986); Tanaboriboon and Guyano (1991); Morrall et al. (1991); Lam et al. (1995); Knoblauch et al. (1996); Koushki (1988); Lam and Cheung (2000); Tarawneh (2001), pedestrian walking speed can be determined by dividing the travel distance by crossing time. Normally, mean pedestrian walking speed or crossing speed will be considered. However, it is recommended that $15^{\text {th }}$ percentile of pedestrian speed can be used as design speed, by assuming that $85 \%$ of pedestrian walk faster than this speed. In contrast, $85^{\text {th }}$ percentile will be the design speed if assume that $15 \%$ of pedestrian walk slower than this speed (Tarawneh, 2001).

When sufficient information has been gathered, pedestrians crossing speed were determined and results were stored into Statistical Package for Social Science (SPSS), a statistical tool used to determine the mean, 15 and 85 percentile of the pedestrian crossing speed. Besides, the Bivariate analysis (chi-square test) was conducted to evaluate the significance of the contributing factors.

\section{Results}

\subsection{Pedestrian Crossing Speed}

Table 1 gives the pedestrian crossing speed for signalised crosswalk in various categories and conditions. Pedestrian crossing times for different conditions are expressed in term of mean speed, $15^{\text {th }}$ percentile speed and $85^{\text {th }}$ percentile speed. Similar findings are presented in Table 2 for non-signalised crosswalk.

At signalised crosswalk, male pedestrians walk faster than female pedestrians do during daytime and night-time. In addition, children pedestrians walk faster than adult and elderly pedestrians do for both daytime and night time. Elderly pedestrians are the slowest group among the age category. Regardless of the categories, the overall mean, $85^{\text {th }}$ percentile speed and $15^{\text {th }}$ percentile speed of pedestrian crossing at signalised crosswalk are $1.31 \mathrm{~m} / \mathrm{s}$, $1.53 \mathrm{~m} / \mathrm{s}$ and $1.09 \mathrm{~m} / \mathrm{s}$, respectively.

Table 2 shows the pedestrian crossing speed at non-signalised crosswalk. Except for male children pedestrians, most of the male pedestrians walk faster than female 
Table 1

Pedestrian Crossing Speed at Signalised Crosswalk $(n=907)$

\begin{tabular}{lcccc}
\hline \multirow{2}{*}{ Condition } & Categories & \multicolumn{3}{c}{ Crossing Speed (m/s) } \\
\cline { 3 - 5 } & & Mean & $85 \%$ & $15 \%$ \\
\hline \multirow{3}{*}{ Daytime } & Male Children & 1.46 & 1.65 & 1.27 \\
& Female Children & 1.35 & 1.56 & 1.07 \\
& Male Adult & 1.41 & 1.65 & 1.20 \\
& Female Adult & 1.31 & 1.47 & 1.17 \\
& Male Elderly & 1.23 & 1.40 & 1.04 \\
& Female Elderly & 1.18 & 1.38 & 1.02 \\
\hline \multirow{3}{*}{ Night time } & Male Children & 1.43 & 1.70 & 1.20 \\
& Female Children & 1.27 & 1.51 & 1.07 \\
& Male Adult & 1.39 & 1.61 & 1.18 \\
\hline Overall & Female Adult & 1.32 & 1.51 & 1.13 \\
\hline
\end{tabular}

Table 2

Pedestrian Crossing Speed at Non-signalised Crosswalk $(n=672)$

\begin{tabular}{lcccc}
\hline \multirow{2}{*}{ Condition } & \multirow{2}{*}{ Categories } & \multicolumn{3}{c}{ Crossing Speed $(\mathbf{m} / \mathbf{s})$} \\
\cline { 2 - 5 } & & Mean & $85 \%$ & $15 \%$ \\
\hline \multirow{3}{*}{ Daytime } & Male Children & 1.44 & 1.61 & 1.29 \\
& Female Children & 1.47 & 1.60 & 1.33 \\
& Male Adult & 1.45 & 1.64 & 1.32 \\
& Female Adult & 1.39 & 1.51 & 1.27 \\
& Male Elderly & 1.43 & 1.69 & 1.20 \\
Night time & Female Elderly & 1.14 & 1.30 & 0.99 \\
& Male Children & 1.54 & 1.78 & 1.34 \\
& Female Children & 1.51 & 1.76 & 1.21 \\
& Male Adult & 1.44 & 1.65 & 1.22 \\
\hline Overall & Female Adult & 1.34 & 1.54 & 1.13 \\
\hline & Male Elderly & 1.35 & 1.58 & 1.12 \\
& Female Elderly & 1.20 & 1.46 & 1.02 \\
\hline
\end{tabular}




\section{Table 3}

Bivariate Analysis Results on Pedestrian Crossing Speed $(n=1579)$

\begin{tabular}{|c|c|c|c|c|c|}
\hline No. & Variable & Chi-Square $\left(\chi^{2}\right)$ & df & $\begin{array}{c}\mathbf{9 5 \%} \\
\text { Significance }\end{array}$ & $\begin{array}{c}\text { Significance } \\
(\mathbf{p}<\mathbf{0 . 0 5})\end{array}$ \\
\hline 1 & Crosswalk type & 38.839 & 1 & 0.001 & Yes \\
\hline 2 & Age categories & 155.033 & 2 & 0.001 & Yes \\
\hline 3 & Gender & 36.196 & 1 & 0.001 & Yes \\
\hline 4 & Lighting & 1.640 & 1 & 0.200 & No \\
\hline 5 & Race & 1.490 & 2 & 0.475 & No \\
\hline
\end{tabular}

pedestrians during daytime and night-time. Overall, children pedestrians are the fastest group among age category, while elderly pedestrians are the slowest. Regardless of other categories, the mean, $85^{\text {th }}$ percentile and $15^{\text {th }}$ percentile of pedestrian crossing speed at non-signalised crosswalk are $1.39 \mathrm{~m} / \mathrm{s}, 1.63$ $\mathrm{m} / \mathrm{s}$ and $1.15 \mathrm{~m} / \mathrm{s}$, respectively.

\subsection{Contributing Factors of Pedestrian Crossing Speed}

Bivariate analysis (chi-square test) results showed that three out of five variables were found significant in its association with pedestrian crossing speed (Table 3 ).

\section{Discussion}

\subsection{Malaysian Pedestrian Crossing Speed}

The mean Malaysian pedestrian speed at non-signalised crosswalk is $1.39 \mathrm{~m} / \mathrm{s}$. This value is higher than countries in Asia (Tanaboriboon et al., 1986; Lam et al., 1995; Morrall et al., 1991) and England (Tanaboriboon and Guyano, 1991) (Table 4). However, for countries like the United States
(Tanaboriboon et al., 1991), Canada (Morrall et al., 1991), and Jordan (Tarawneh, 2001), the pedestrians' speeds are slightly similar.

Table 4

Comparison of Pedestrian Walking Speeds in Different Countries

\begin{tabular}{cc}
\hline \multicolumn{1}{c}{ Country } & $\begin{array}{c}\text { Mean Walking Speed } \\
(\mathbf{m} / \mathbf{s})\end{array}$ \\
\hline Asia & \\
$\quad$ Riyadh, Saudi Arabia & 1.08 \\
$\quad$ Madras, India & 1.20 \\
$\quad$ Hong Kong & 1.20 \\
$\quad$ Thailand & 1.22 \\
$\quad$ Singapore & 1.23 \\
Colombo, Sri Lanka & 1.25 \\
$\quad$ Israel & 1.31 \\
$\quad$ Malaysia & 1.39 \\
England & 1.31 \\
United States & \\
$\quad$ Columbia & 1.32 \\
$\quad$ New York & 1.35 \\
$\quad$ Pittsburgh & 1.47 \\
Calgary, Canada & 1.40 \\
Jordan & 1.34 \\
\hline
\end{tabular}


In comparison to other Asian countries, such as Singapore and Thailand, Malaysian pedestrians walk the fastest. This could be due to the physical differences among pedestrians (e.g. height) and cultural differences (e.g. in dress and shopping habits). For example, taller pedestrians have longer footsteps, thus their movement length are greater in distance compared to those who are shorter. Inconvenient dressing such as, traditional custom could also influence the walking speed of pedestrian in terms of free movement of both footsteps. Similar findings have been reported by Tanaboriboon et al. (1986) and Tanaboriboon and Guyano (1991).

Meanwhile, for signalised crosswalk in Malaysia, the mean pedestrian speed is $1.31 \mathrm{~m} / \mathrm{s}$, which is lesser than mean speed at non-signalised crosswalk. As most of the studies conducted did not emphasize on this consideration in determining pedestrian speed, it is not possible to carry out a comparison on this value.

\subsection{Contributing Factors}

\subsubsection{Crosswalk Type}

Pedestrians at non-signalised crosswalk walk faster than at signalised crosswalk. Thus, the result shows that there is a difference in terms of crosswalk type and pedestrian speed. At signalised crosswalk, pedestrians are always given right of way to cross safely. However, this scenario is different at non-signalised crosswalk. Pedestrians are not protected and are always at risk while crossing. Their risk index and exposures are even higher than at signalised crosswalk. Hence, they are urged to walk faster and it is reasonable to accept this fact. This contributing factor is in line with some research conducted (Tanaboriboon et al., 1986; Tanaboriboon and Guyano, 1991).

\subsubsection{Age}

There is a significant difference in terms of age and pedestrian crossing speed. Findings indicate that elderly pedestrian, with age greater than 55 years old, are likely to walk slower. This explains why pedestrian accident mainly involves elderly pedestrian. Insufficient time to cross safely may lead to road accident involving elderly pedestrian and the roadway design should consider this.

In contrast, children pedestrians (age less than 20 years old) are the fastest group. This is mainly because children pedestrian as the youngest group are generally very energetic. Furthermore, their reaction is faster than elderly group. Road accident involving children might not necessarily be due to crossing time, since they do walk faster than other groups, it might be contributed by other factors, such as playing while crossing, low visibility of appearance due to their small size on the road or lack of proper safe crossing facilities. Similar findings were also supported by Tanaboriboon et al. (1986); Tanaboriboon and Guyano (1991); Morrall et al. (1991); Bowman and Vecellio (1994); Knoblauch et al. (1996); Oxley et al. (1997) and Tarawneh (2001).

\subsubsection{Gender}

There is a strong relationship between pedestrian speed and gender. Male pedestrians were more likely to walk faster than females when crossing the road. This is in line with some studies reported (Tanaboriboon et al., 1986; Tanaboriboon and Guyano, 1991; Morrall et al., 1991; Lam et al., 1995; Knoblauch et al., 1996; Koushki, 1988; Lam and Cheung, 2000; Tarawneh, 2001). Men usually give less priority for safety compared to women. So far, the general conclusion is that male 
pedestrians walk faster than female pedestrians do. Therefore, they are more vulnerable group, especially if they are rushing and thus paying less attention, which could lead to road accident. This explains why many road accident cases involve male pedestrian.

\subsubsection{Lighting}

There is no association between lighting (daytime or night-time) and pedestrian' speed. No matter daytime or night time, pedestrian speed will not be affected. Hence, lighting is not a contributing factor on the pedestrian crossing speed. Unfortunately, there are not many studies carried out to validate on this factor. However, lighting is very important to improve the visibility of pedestrian to drivers.

\subsubsection{Race}

Race was found as a non-contributing factor in influencing the pedestrians' speed. There is no association between race and pedestrian speed. Perhaps, most Malaysian has similar lifestyle here and they behave and practice quite close behaviour while on road. This may be the reason why there is no association between race and pedestrian speed.

\section{Conclusion}

Based on the findings, the following conclusions were drawn regarding pedestrian speed in Malaysia:

- The mean, $85^{\text {th }}$ percentile and $15^{\text {th }}$ percentile pedestrian speeds at signalised crosswalk in Malaysia are $1.31 \mathrm{~m} / \mathrm{s}, 1.53 \mathrm{~m} / \mathrm{s}, 1.09 \mathrm{~m} / \mathrm{s}$, respectively.

- For non-signalised crosswalk, the mean, 85 th percentile and 15 th percentile pedestrian speeds in Malaysia are $1.39 \mathrm{~m} / \mathrm{s}$, $1.63 \mathrm{~m} / \mathrm{s}, 1.15 \mathrm{~m} / \mathrm{s}$, respectively.
- Crosswalk type, age and gender significantly contribute to pedestrian speed in Malaysia.

- Lighting and race are not contributing factors of the pedestrian' speed.

- Pedestrian at non-signalised crosswalk have significantly faster crossing speed than at signalised crosswalk.

- Children pedestrian (less than 20 years old) are the fastest group, whereas elderly pedestrian (greater than 55 years old) are the lowest group. In future, consideration should be given to elderly pedestrian to ensure they have a safe crossing on road.

- Male pedestrian have significantly faster crossing speed than female pedestrian. As female pedestrians walk slower, it should be included in the consideration of pedestrian accident study.

- Current design on traffic signal using 1.22 $\mathrm{m} / \mathrm{s}$ does not provide sufficient time for pedestrian to cross safely. Perhaps, this may be one of the main reasons why pedestrians at signalised crosswalk tend to cross faster.

To promote the pedestrian safety, it is recommended such results to be incorporated for traffic control design and more relevant studies should be carried out to further investigate the contributing factors of pedestrian speed.

\section{References}

Bowman, B.L.; Vecellio, R.L. 1994. Pedestrian Walking Speeds and Conflicts at Urban Median Locations, Transportation Research Record, 1438: 67-73.

Jabatan Kerja Raya (JKR). 1987. Arahan Teknik (Jalan) 13/87. A Guide to the Design of Traffic Signal. 107 p.

Knoblauch, R.L.; Pietrucha, M.T.; Nitzburg, M. 1996. Field Studies of Pedestrian Walking Speed and Start-up Time, Transportation Research Record. DOI: http://dx.doi. org/10.3141/1538-04, 1538: 27-38. 
Koushki, P.A. 1988. Walking Characteristics in Central Riydah, Saudi Arabia, Journal of Transportation Engineering. DOI: http://dx.doi.org/10.1061/(ASCE)0733947X(1988)114:6(735), 114(6): 735-744.

Lam, W.K.L.; Cheung, C. 2000. Pedestrian Speed / Flow Relationship for Walking Facilities in Hong Kong, Journal of Transportation Engineering. DOI: http://dx.doi.org/10.1061/ (ASCE)0733-947X(2000)126:4(343), 126(4): 343-349.

Lam, W.K.L.; Morrall, J.F.; Ho, H. 1995. Pedestrian Flow Characteristics in Hong Kong, Transportation Research Record, 1487: 56-62.

Morrall, J.F.; Ratnayake, L.L.; Seveviratne, P.N. 1991. Comparison of Central Business District Pedestrian Characteristics in Canada and Sri Lanka, Transportation Research Record, 1294: 57-61.

Oxley, J.; Fildes, B.; Elfriede, I.; Chartons, J.; Day, R. 1997. Differences in Traffic Judgments between Young and Old Adult Pedestrians, Accident Analysis and Prevention. DOI: http://dx.doi.org/10.1016/S0001-4575(97)00053-5, 29(6): 839-847.

Royal Malaysian Police (PDRM). 2004. Statistical Report Road Accidents Malaysia - 2003.

Tanaboriboon, Y.; Guyano, J.A. 1991. Analysis of Pedestrian Movements in Bangkok, Transportation Research Record, 1294: 52-56.

Tanaboriboon, Y.; Sim, S.H.; Chin, H.C. 1986. Pedestrian Characteristics Study in Singapore, Journal of Transportation Engineering. DOI: http://dx.doi.org/10.1061/ (ASCE)0733-947X(1986)112:3(229), 112(3): 229-235

Tarawneh, M.S. 2001. Evaluation of Pedestrian Speed in Jordon with Investigation of Some Contributing Factors, Journal of Safety Research. DOI: http://dx.doi.org/10.1016/ S0022-4375(01)00046-9, 32(2): 229-236.

\section{BRZINA KRETANJA PEŠAKA NA PEŠAČKOM PRELAZU: PRIMER MALEZIJE}

\section{Boon Hoe Goh, Kulanthayan \\ Subramaniam, Yeong Tuck Wai, Abdullahi Ali Mohamed}

Sažetak: Pešaci su ranjivi učesnici u saobraćaju i svakodnevno su izloženi riziku. Shodno tome, projektovanje kolovoza i postavljanje uređaja za regulisanje saobraćaja treba da obuhvati bezbednost pešaka. Brzina hoda pešaka je od suštinske važnosti za svaki kolovoz i regulisanje saobraćaja. Nažalost, u Maleziji ne postoje određene smernice kada je reč o brzini pešaka na pešačkom prelazu. Krajnji cilj ovog istraživanja je da se utvrdi brzina kojom pešaci prelaze pešački prelaz na lokalnom nivou i da se identifikuju relevantni faktori. Prikupljeno je ukupno 1579 uzoraka brzine kojom pešaci prelaze pešačke prelaze sa i bez signalizacije. Izvršena je statistička Bivariate analiza (hi-kvadrat test) kako bi se ustanovila relacija između relevantnih faktora. Bivariate analiza pokazuje da tip pešačkog prelaza, godište i pol značajno utiču na brzinu hoda pešaka u Maleziji. Sa druge strane, pokazano je da osvetljenje (dnevno i noćno) i rasa ne utiču na brzinu hoda pešaka. Osim toga, pešaci na pešačkim prelazima bez signalizacije imaju značajno veću brzinu prelaženja nego na pešačkim prelazima sa signalizacijom. Hi-kvadrat test je takođe pokazao da su deca pešaci najbrža grupa, a stariji pešaci najsporija kada je reč o brzini kretanja pešaka na pešačkom prelazu. Pored toga, u studiji je pokazano da muškarci značajno brže prelaze kolovoz nego žene.

Ključne reči: brzina hodanja, brzina prelaženja kolovoza, pešački prelaz sa/bez signalizacije, hi-kvadrat test. 